\title{
Necropolíticas e adoecimento: genocídio negro, gênero e sofrimento
}

\author{
Necropolitics and illness: black genocide, gender, \\ and suffering
}

\author{
Necropolíticas y enfermedad: genocidio negro, \\ género y sufrimiento
}

Brito MD. NÃO. ELE NÃO ESTÁ. Curitiba:Appris Editora; 2018. 117 p. ISBN 978-85-473-2148-2.

doi: 10.1590/0102-311X00075319

Um dos mais evidentes vetores do racismo no Brasil é o extermínio da juventude negra 1. A tragédia social do genocídio negro tem sido amplamente estudada por pesquisadores dos campos da segurança pública, ciências sociais e ciências da saúde, em um esforço duplo de caracterizá-lo e, na medida em que produzem evidências de sua dimensão, profundidade e gravidade, combatê-lo. Nesse campo, o conceito de necropolítica, cunhado por Achille Mbembe, vem ganhando relevância política e analítica. Referindo-se às "formas contemporâneas que subjugam a vida ao poder da morte" 2 (p. 146) a noção de necropolítica permite reconhecer, nas mortes de jovens negros, uma face seletiva de produção de morte constitutiva da modernidade.

No livro Não. Ele Não Está, Maíra de Deus Brito avança na caracterização das dimensões que compõem o genocídio negro e, nesse passo, aposta na potência da noção de necropolítica para articular questões relativas à violência de estado, ao adoecimento e ao gênero. O título oferece a porta de entrada para nos aproximarmos do ângulo escolhido pela autora, jornalista e especialista em políticas públicas em gênero e raça, para apresentar os resultados de sua pesquisa de mestrado em Direitos Humanos. Não. Ele não está é uma resposta negativa a alguém que procura por um terceiro, que se encontra ausente. A voz que responde é a de mulheres negras residentes nas periferias urbanas brasileiras, que perderam seus filhos para a violência de estado. É da dolorida e adoecedora ausência dos filhos, brutal e abruptamente assassinados, vivenciada por mulheres negras e periféricas, de suas angústias, adoecimentos, afetos e resistências de que se trata o livro.

Em três capítulos, a obra desliza entre a competente e necessária apresentação das condições de realização da pesquisa, as histórias de vida das interlocutoras e as pertinentes análises, que ecoam as vozes de intelectuais negras e negros e, como parte desse coro, a da própria autora. No primeiro capítulo, Maíra de Deus Brito apresenta suas idas e vindas por questões que abrangem desde a própria decisão do tema da pesquisa até seus trajetos pelo Rio de Janeiro, onde decidira fazer trabalho de campo. Afetada por notícias recorrentes de assassinatos de jovens negros e arrebatada pelo reconhecimento de que "nós estamos sendo mortos", a autora entendeu ser pertinente tratar não só dos acontecimentos que deixam jovens negros mortos, mas também das repercussões desses sobre as experiências de mães que se veem repentinamente sem seus filhos. A pesquisa se apresenta, portanto, como uma interlocução entre mulheres negras, fato esse que, conforme descrito pela autora, permitiu que suas entrevistadas se sentissem melhor ouvidas, aco- 
lhidas e compreendidas, bem como demarcou o compromisso político da obra.

No capítulo dois, seção mais densa do livro, entramos nas histórias das duas mulheres entrevistadas por Maíra. Ana Paula e Aparecida protagonizam narrativas de suas próprias histórias de vida. Ao contarem sobre como remoções forçadas e deslocamentos diversos as levaram a residirem em favelas cariocas, como conseguiram - apesar dos pesares - se qualificarem educacional e profissionalmente e como, em meio ao convívio com abordagens policias diversas, vieram a perder seus filhos, somos colocados diante de cenários extensivos de violência. De modo perspicaz, a autora não nos deixa perder de vista o fato de que o assassinato dos filhos de Aparecida e Ana, respectivamente com 19 e 30 anos, marca uma mudança brusca em suas vidas, já então marcadas pelo convívio com a brutalidade policial, ausência de políticas sociais e condições precárias de saúde, habitação e transporte.

A violência não era, portanto, algo novo na vida dessas mulheres. $\mathrm{O}$ assassinato de seus filhos, contudo, inaugurou uma nova trajetória de sofrimento e adoecimento das mais diversas ordens - não só das mães, mas também de avós, sobrinhas, irmãs e outros familiares. $\mathrm{O}$ assassinato provocara uma ruptura, nas suas palavras, uma “dor que não cicatriza”, "uma ferida aberta” (p. 55). Para além da dor da perda de um filho, as interlocutoras da pesquisa relataram terem sido elas e seus familiares acometidos por adoecimentos como "diabetes emocional" (p. 46), "insônia crônica”, "hipertensão", "depressão" (p. 61) e "problemas de memória” (p. 62), todos eles desenvolvidos ou severamente agravados após o assassinato. Um caso particularmente grave é o da avó de Ana Paula, que falecera três meses após a execução do bisneto. Conforme registrado em seu relato, "Minha avó ficou muito pior depois da morte dele. Eu e minha família acreditamos que foi em decorrência do assassinato" (p. 62).

Sensível e atenta ao espraiamento da morte em processos de adoecimento, sofrimento e mesmo óbito decorrentes da morte dos jovens negros, Maíra Brito seguiu, no terceiro e último capítulo, para uma reflexão a respeito do modo com que racismo, sexismo e classismo se articulam da produção da violência ininterrupta do estado. O corpo negro na favela é alvo central da reflexão da autora, que analisa os modos com que políticas históricas de perseguição de sujeitos negros - como as de criminalização da "vadiagem" e os "autos de resistência" - constituem instrumentos fundamentais de exercício da violência estatal, de modo que direitos fundamentais se constituíram de modos absolutamente estranhos à população negra. Confrontando a pretensa universalidade dos direitos humanos, que tem em sujeitos brancos a medida da humanidade, a autora tensiona o modo com que a brutalidade das necropolíticas escancaram o estatuto não humano de sujeitos negros diante de padrões humanitários da branquitude. Para Maíra Brito, o extermínio da juventude negra é parte de um antigo projeto de nação brasileira, no qual, ao lado da miscigenação, a eliminação de sujeitos negros promove o embranquecimento da população.

$\mathrm{Na}$ medida em que reconhecemos o racismo como um vetor estruturante de relações sociais no Brasil e da violência perpetrada contra os negros, encontramos um caminho para aproximarmos Não. Ele Não Está do campo da saúde coletiva. O que temos diante de nós é um registro analítico e político do modo com que o racismo participa e condiciona as dimensões, profundidades, modos e extensões de adoecimento e morte da população negra. Temas fundamentais e de associação mais imediata são elaborados no trabalho, como a fragilizada saúde mental das mulheres negras vitimadas pela execução de seus filhos. Por outro lado, o trabalho não negligencia outros adoecimentos que, igualmente associados às mortes e às condições de vida precarizadas, são prevalentes na população negra. Nesse sentido, o livro contribui não só com o adensamento de investigações sobre as interpelações do racismo na saúde - em especial, de mulheres negras 3 , mais do que isso, permite que estudiosos da saúde se aproximem do conceito de necropolítica como ferramenta teórica e analítica para compreensão e transformação das condições de saúde e de vida 
da população negra. Indissociadas, tais possibilidades de leitura e interlocução com o trabalho de Maíra de Deus Brito denotam o quanto sua potência política não se perde em suas pertinentes contribuições empíricas, analíticas e reflexivas. Ao contrário, tais dimensões fortalecem o corpo de estudos sobre a questão racial no Brasil e suas diversas interfaces e as possibilidades de intervenção antirracista.

Rosana Castro 1

1 Universidade do Estado do Rio de Janeiro, Rio de Janeiro, Brasil.

rosana.rc.castro@gmail.com

\section{Informação adicional}

ORCID: Rosana Castro (0000-0002-1069-4785).

1. Carneiro AS. A construção do Outro como Não-Ser como fundamento do Ser [Tese de Doutorado]. São Paulo: Programa de Pós-graduação em Educação, Universidade de São Paulo; 2005.

2. Mbembe A. Necropolítica. Arte \& Ensaios 2016; (32):123-51.

3. Werneck J. Racismo institucional e saúde da população negra. Saúde Soc 2016; 25:53-49. 